\title{
Influence of marine reserves on coral disease prevalence
}

\author{
Cathie A. Page ${ }^{1, *}$, David M. Baker ${ }^{2}$, C. Drew Harvell ${ }^{2}$, Yimnang Golbuu ${ }^{3}$, \\ Laurie Raymundo ${ }^{4,5}$, Stephen J. Neale ${ }^{6,7}$, Kathryn B. Rosell ${ }^{4}$, Krystal L. Rypien ${ }^{2}$, \\ Jason P. Andras ${ }^{2}$, Bette L.Willis ${ }^{1}$ \\ ${ }^{1}$ School of Marine and Tropical Biology and ARC Centre of Excellence for Coral Reef Studies, James Cook University, \\ Townsville, Queensland 4811, Australia \\ ${ }^{2}$ Department of Ecology and Evolutionary Biol ogy, Cornell University, Ithaca, New York, 14843, USA \\ ${ }^{3}$ Palau International Coral Reef Centre, PO Box 7086, Koror 96940, Republic of Palau \\ ${ }^{4}$ Silliman University Marine Laboratory, Dumaguete City 6200, Philippines \\ ${ }^{5}$ Marine Laboratory, University of Guam, UOG Station, Mangilao 96923, Guam \\ ${ }^{6}$ Australian Institute of Marine Science, PMB 3, Townsville, Queensland 4810, Australia \\ ${ }^{7}$ Present address: Sinclair Knight Merz, 11th Floor, Durack Centre, 263 Adelaide Terrace, Perth, Western Australia 6001, \\ Australia
}

\begin{abstract}
Predicted increases in disease with climate warming highlight the need for effective management strategies to mitigate disease effects in coral communities. We examined the role of marine protected areas (MPAs) in reducing disease in corals and the hypothesis that the composition of fish communities can influence coral health, by comparing disease prevalence between MPA and non-protected (control) reefs in Palau. Overall, the prevalence of diseases pooled, as well as the prevalence of skeletal eroding band (SEB), brown band disease (BrB) and growth anomalies (GAs) individually in major disease hosts (families Acroporidae and Poritidae), were not significantly reduced within MPAs. In fact, the prevalence of SEB was 2-fold higher within MPAs overall; however, the 4 studied MPAs were ineffective in enhancing coral assemblage or fish stock health. A negative association between the prevalence of SEB and richness of a fish species targeted by fishers in Palau highlights the potential role that well-managed MPAs could play in reducing SEB. The composition of coral communities and their susceptibility to bleaching also influenced the prevalence of disease on the studied reefs. The prevalence of diseases pooled and SEB were positively associated with the cover of major disease hosts (families Acroporidae and Poritidae), and the prevalence of BrB and bleaching were also positively associated. Although our study did not show positive effects of MPAs on coral heath, we did identify the potential for increased fish diversity within MPAs to reduce coral disease. Our study also highlights the complexity of relationships between fish assemblages, coral community composition and coral health on Indo-Pacific reefs.
\end{abstract}

KEY WORDS: Coral disease $\cdot$ Skeletal eroding band $\cdot$ Brown band disease $\cdot$ Growth anomalies $\cdot$ Coral bleaching $\cdot$ Marine protected area $\cdot$ Marine reserve $\cdot$ Indo-Pacific

Resale or republication not permitted without written consent of the publisher

\section{INTRODUCTION}

Coral reef ecosystems are increasingly threatened, particularly by overfishing, pollution and climate change, which are driving global declines in coral reef diversity and coral reef health (Barber et al. 2001, Jack- son et al. 2001, Gardner et al. 2003, Hughes et al. 2003). Exploitation of reef fish stocks (Bellwood et al. 2003, Dulvy et al. 2003) and loss of functional redundancy in reef fish assemblages (Bellwood et al. 2003) are affecting the very structure and function of coral reef ecosystems (Dulvy et al. 2004, Graham et al. 2006). 
Marine protected areas (MPAs) are useful tools for managing coral reef fisheries, particularly exploited fish stocks (Russ 2002, Halpern 2003), effectively increasing the abundance, individual size and overall biomass of reef fish (Polunin \& Roberts 1993, Russ 2002, Halpern 2003, Evans \& Russ 2004, Williamson et al. 2004). MPAs have also enhanced stocks of exploited coral reef invertebrates (Kelly et al. 2000, Halpern 2003, Ashworth et al. 2004, Uthicke et al. 2004), but their role in the management of reef corals is less clear.

Given the strong dependence of many exploited reef fish on corals for food and habitat (Williams 1986, Shibuno et al. 1999, Kokita \& Nakazono 2001), it is surprising that considerably fewer studies have documented the effects of MPAs on coral communities. Those that have, found the influence of MPAs on coral communities to be variable. MPAs in Kenya (McClanahan \& Muthiga 1988, McClanahan \& Mutere 1994, McClanahan 1997) and on the Great Barrier Reef (Williamson et al. 2004) have successfully enhanced either the abundance or cover of hard corals. In contrast, the cover of scleractinian corals was lower within 'no-take' zones on Glovers Reef, Belize (McClanahan et al. 2001). MPAs also failed to mitigate declines in coral cover on reefs in Papua New Guinea (Jones et al. 2004a) and on Little Cayman Island in the Caribbean (Coelho \& Manfrino 2007). Also, MPAs failed to consistently enhance the cover of corals or protect corals from physical damage in the Philippines, Malaysia and Indonesia (White 1986). These results were predominately due to a lack of compliance with MPA restrictions or losses of corals from bleaching, anthropogenic pollution and sedimentation, the influence of which permeate MPA boundaries. Although it has been suggested that MPAs could enhance the resilience of coral reefs (Done 2001), their utility in mitigating epizootics in coral populations has been quantitatively investigated in only 2 studies (Coelho \& Manfrino 2007, McClanahan et al. 2008).

Comparisons of the prevalence of growth anomalies on Porites colonies in Kenya (McClanahan et al. 2008) and the prevalence of several diseases at Little Cayman in the Caribbean (Coelho \& Manfrino 2007) indicate that MPAs were not effective in reducing disease in these reef regions. Nonetheless, several lines of reasoning predict that MPAs should reduce the progression and spread of disease throughout coral populations. For instance, intact fish biodiversity and ecosystem functioning within MPAs, particularly the presence of a wide range of feeding guilds, contributing to the balance between corals, competitors and potential vectors or reservoirs of pathogens, could enhance the resilience of corals to pathogens. Experimental studies of plant communities also suggest that high diversity results in a decreased incidence of disease via reductions in horizontal transmission of pathogens between susceptible hosts (Mitchell et al. 2002); thus, increased coral diversity within MPAs could directly decrease disease prevalence. Given the lack of specificity of many coral diseases (Weil et al. 2002, Willis et al. 2004, Page \& Willis 2006) and the potential for rapid spread of disease in the marine environment (McCallum et al. 2003), the potential for increased diversity of corals within MPAs to mitigate disease is unclear. MPAs that exclude destructive fishing methods and other activities that damage corals may also reduce disease prevalence by limiting coral injury, which has been implicated in the initiation of coral disease (Bak \& Criens 1981, Antonius \& Riegl 1997, 1998, Page \& Willis 2008). Finally, intact fish communities within MPAs are most likely to contain feeding guilds that prey on corallivores, which are the most common vectors of diseases in corals (Sussman et al. 2003, Williams \& Miller 2005, Dalton \& Godwin 2006), either through predation, injury or pathogen transmission. Similarly, a high abundance of herbivorous fish within MPAs would limit algal growth (Bellwood et al. 2006, Mumby et al. 2006) and consequently negative algal-coral interactions (Jompa \& McCook 2003) that might facilitate invasion of corals by pathogens (Nugues et al. 2004, Smith et al. 2006). The potential for MPAs to limit populations of corallivores and macroalgae to low densities through increased abundance of higher order predators and grazers is likely to be an important role for MPAs in disease mitigation.

Conversely, MPAs might facilitate the spread of disease through coral populations for a variety of reasons. Increased host densities, predicted if levels of damaging activities are reduced, facilitate the spread of pathogens throughout populations of susceptible hosts (Anderson \& May 1979). Increased disease in highdensity populations of Diadema urchins, as a consequence of low predator abundance outside of MPAs (Lafferty 2004), illustrates this possibility in a marine environment. MPAs are also likely to increase disease prevalence if they increase densities of fishes that are vectors for coral pathogens or that injure coral tissues during feeding, thereby providing opportunities for entry of pathogens and the development of disease. For example, butterflyfish are a known vector of trematodiasis in Hawaiian corals (Aeby 1991) and increase the spread of black band disease (Aeby \& Santavy 2006). Finally, while well-managed MPAs with enhanced fish stocks are aesthetically pleasing, they may facilitate the spread of coral diseases if they provide for multiuse activities like tourism that result in inputs of novel pathogens, nutrients or increased levels of coral damage from snorkellers and divers.

The need for management strategies to maintain and enhance coral health and to manage the dynamics of 
both pathogens and parasites in reef communities is becoming increasingly urgent (Lafferty 2004, Sasal et al. 2004, McCallum et al. 2005, Ward et al. 2006). Of particular concern are dramatic declines of Caribbean coral populations due to disease (Aronson \& Precht 2001, Porter et al. 2001, Patterson et al. 2002), recent trends for increasing disease outbreaks in corals and other marine groups globally (Ward \& Lafferty 2004, Sokolow 2009, this Special), and predictions of further increases in disease outbreaks with ocean warming (Harvell et al. 1999, 2002, IPCC 2002, Bruno et al. 2007). Given the limited number of options available for managing diseases in marine environments (Bruckner 2002, Harvell et al. 2004, McCallum et al. 2005) and the current popularity of MPAs as a reef fisheries management tool, we examined the potential role of MPAs in reducing coral disease on Indo-Pacific reefs by comparing disease prevalence on reefs within and outside of MPAs in the Republic of Palau. We also assessed the effectiveness of the sampled MPAs using measures of coral and fish community diversity and compared coral disease prevalence on reefs in contrasting environments to gain insights into factors influencing the prevalence of coral disease on reefs in Palau.

\section{MATERIALS AND METHODS}

Site description. To determine if MPAs influence coral health and specifically the prevalence of coral disease, we compared coral disease prevalence and selected measures of coral health within and outside of MPAs in 4 regions, spread over at least $50 \mathrm{~km}$ of coastline in the Republic of Palau $\left(7^{\circ} \mathrm{N}, 134^{\circ} \mathrm{E}\right.$; Fig. 1). Within each of the 4 regions, 2 sites were haphazardly chosen from within an MPA, while 2 sites matching in terms of depth, reef habitats and coral assemblages were haphazardly chosen from non-protected reefs nearby each MPA. Three of 4 managed reefs were legally-designated MPAs (Ngelukes, Ngemelis, Cemetery Reef) and one was unofficially considered to be an MPA (Bital Rirs) based on knowledge that no fishing occurs at the location. MPAs ranged in size from 0.008 to $30 \mathrm{~km}^{2}$ and in age from 3 to $10 \mathrm{yr}$. Given their geographical spread (Fig. 1), reefs in the 4 studied regions were located in a unique environmental setting and consequently differed in terms of reef habitats, oceanographic and anthropogenic effects and composition of coral communities (Table 1).

Quantifying coral disease and coral community structure. In January 2005, coral disease prevalence

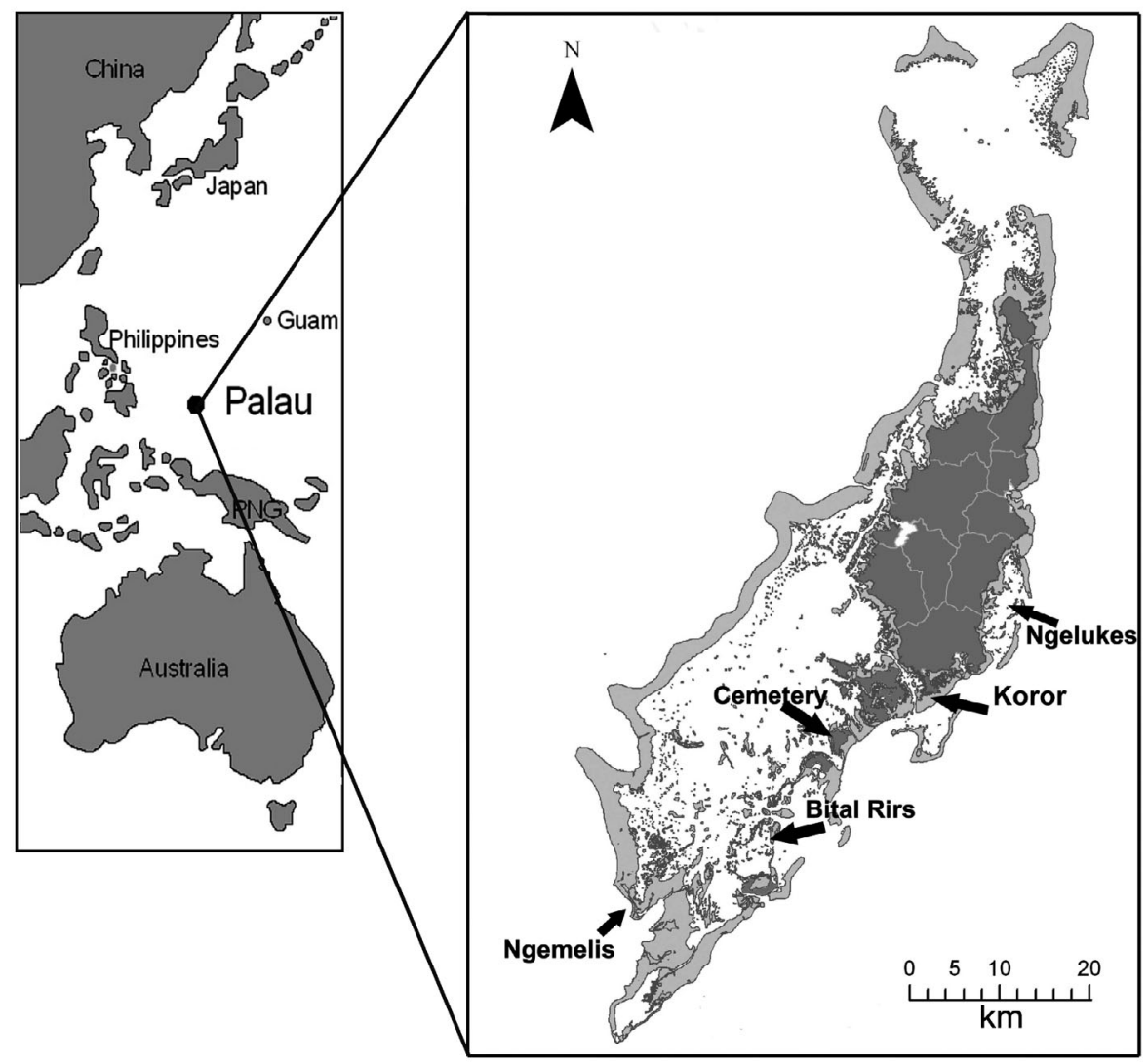

Fig. 1. Locations in Palau (Indo-Pacific) of marine protected areas and paired control reefs (shown as a single arrow), and the main population centre of Koror 
Table 1. Characteristics of marine protected areas (MPA) and paired control reefs in 4 regions of Palau, including date of MPA establishment, area of reef within MPA, activities excluded from MPAs, other effects experienced by reefs, coral community composition, latitude and longitude

\begin{tabular}{|c|c|c|c|c|c|c|c|}
\hline $\begin{array}{l}\text { Region or } \\
\text { MPA name }\end{array}$ & $\begin{array}{l}\text { MPA/ } \\
\text { Control }\end{array}$ & $\begin{array}{l}\text { Date MPA } \\
\text { established }\end{array}$ & $\begin{array}{l}\text { Activities } \\
\text { excluded } \\
\text { in MPA }\end{array}$ & $\begin{array}{l}\text { Area } \\
\left(\mathrm{km}^{2}\right)\end{array}$ & Other effects & $\begin{array}{l}\text { Coral community } \\
\text { characteristics }\end{array}$ & Location \\
\hline \multirow[t]{2}{*}{ Ngelukes } & MPA & 2002 & Fishing, entry & 1 & $\begin{array}{l}\text { High levels of runoff } \\
\text { from agriculture, roads } \\
\text { and other developments, } \\
\text { low water visibility and } \\
\text { rates of water flow and } \\
\text { flushing }\end{array}$ & $\begin{array}{l}\text { Coral density variable, } \\
\text { Porites, Acropora, } \\
\text { Pocillopora dominated }\end{array}$ & $\begin{array}{l}7^{\circ} 25^{\prime} \mathrm{N} \\
134^{\circ} 36^{\prime} \mathrm{E}\end{array}$ \\
\hline & Control & & & & $\begin{array}{l}\text { High levels of runoff from } \\
\text { agriculture, road and } \\
\text { other developments, low } \\
\text { water visibility and rates } \\
\text { of water flow and flushing }\end{array}$ & $\begin{array}{l}\text { Moderate coral density, } \\
\text { Acropora and Porites } \\
\text { dominated }\end{array}$ & $\begin{array}{l}7^{\circ} 24^{\prime} \mathrm{N} \\
134^{\circ} 35^{\prime} \mathrm{E}\end{array}$ \\
\hline \multirow[t]{2}{*}{ Cemetery } & MPA & 1999 & $\begin{array}{l}\text { All extractive } \\
\text { activities }\end{array}$ & 0.008 & $\begin{array}{l}\text { High tourist visitation and } \\
\text { fish feeding, moderate } \\
\text { visibility, water flow and } \\
\text { flushing }\end{array}$ & $\begin{array}{l}\text { Moderate coral density, } \\
\text { Porites dominated }\end{array}$ & $\begin{array}{l}7^{\circ} 14^{\prime} \mathrm{N} \\
134^{\circ} 22^{\prime} \mathrm{E}\end{array}$ \\
\hline & Control & & & & $\begin{array}{l}\text { Moderate visibility, water } \\
\text { flow and flushing }\end{array}$ & $\begin{array}{l}\text { Moderate to low coral } \\
\text { density, Porites dominated }\end{array}$ & $\begin{array}{l}7^{\circ} 14^{\prime} \mathrm{N} \\
134^{\circ} 22^{\prime} \mathrm{E}\end{array}$ \\
\hline \multirow[t]{2}{*}{ Bital Rirs } & MPA & $\begin{array}{l}\text { Not official } \\
\text { MPA, but } \\
\text { no fishing } \\
\text { occurs here }\end{array}$ & Fishing & 0.008 & $\begin{array}{l}\text { Moderate tourist visitation, } \\
\text { moderate visibility, high } \\
\text { water flow and flushing }\end{array}$ & $\begin{array}{l}\text { Moderate to low coral } \\
\text { density, Acropora } \\
\text { dominated }\end{array}$ & $\begin{array}{l}7^{\circ} 13^{\prime} \mathrm{N} \\
134^{\circ} 23^{\prime} \mathrm{E}\end{array}$ \\
\hline & Control & & & & $\begin{array}{l}\text { Moderate visibility, high } \\
\text { water flow and flushing }\end{array}$ & $\begin{array}{l}\text { Moderate coral density, } \\
\text { Acropora dominated }\end{array}$ & $\begin{array}{l}7^{\circ} 12^{\prime} \mathrm{N} \\
134^{\circ} 23^{\prime} \mathrm{E}\end{array}$ \\
\hline \multirow[t]{2}{*}{ Ngemelis } & MPA & 1995 & $\begin{array}{l}\text { Fishing within } \\
2 \text { miles }(\sim 3.2 \mathrm{~km}) \\
\text { of MPA boundary }\end{array}$ & 30 & $\begin{array}{l}\text { High tourist visitation, } \\
\text { upwelling, high visibility, } \\
\text { high water flow and } \\
\text { flushing }\end{array}$ & $\begin{array}{l}\text { High to moderate coral } \\
\text { density, Porites and } \\
\text { Favid dominated }\end{array}$ & $\begin{array}{l}7^{\circ} 06^{\prime} \mathrm{N} \\
134^{\circ} 14^{\prime} \mathrm{E}\end{array}$ \\
\hline & Control & & & & $\begin{array}{l}\text { High tourist visitation, } \\
\text { upwelling, high visibility, } \\
\text { water flow and flushing }\end{array}$ & $\begin{array}{l}\text { High coral density, } \\
\text { Porites dominated }\end{array}$ & $\begin{array}{l}7^{\circ} 04^{\prime} \mathrm{N} \\
134^{\circ} 15^{\prime} \mathrm{E}\end{array}$ \\
\hline
\end{tabular}

was documented from within each site, a site consisting of 3 haphazardly-placed $20 \times 2 \mathrm{~m}$ belt transects placed on the upper reef slope, parallel to the reef crest and along depth contours between 3 and $8 \mathrm{~m}$. Within $1 \mathrm{~m}$ belts on each side of the central transect tape, all hard corals, soft corals, antipatharians and gorgonians were identified to the lowest taxonomic level recognised or morphological group, as appropriate. Each physiologically discrete colony was then categorised as healthy, bleached, compromised or diseased as described by Willis et al. (2004) and Raymundo et al. (2005). The bleached category included corals with either partial or whole colony losses of tissue pigmentation. The compromised category included corals with (1) feeding scars from corallivores, such as crown-ofthorns starfish Acanthaster planci, Drupella snails or reef fishes; (2) pigmentation responses to a variety of challenges (e.g. competitive interactions, injury, boring organisms); and (3) tissue loss due to competitive interactions with algae and other benthic organisms (i.e. invading or overgrowing live coral tissue). Samples of diseased colonies were collected and examined microscopically to identify associated micro-organisms and to verify field identifications of diseases.

Approximately $90 \%$ of all disease cases and other signs of compromised coral health (bleaching and other changes in colony pigmentation, injury from predators, overgrowth by benthic organisms) were recorded from the families Acroporidae and Poritidae. Thus only these families were included in prevalence calculations for the diseased, bleached and compromised categories. Over $90 \%$ of diseased colonies were categorised as having brown band disease $(\mathrm{BrB})$, skeletal eroding band (SEB) or growth anomalies (GAs; examples shown in Fig. 2). Thus, the prevalence of these 3 diseases was calculated separately.

Measures of MPA effectiveness. The cover of corals and all other benthos was measured from under all 


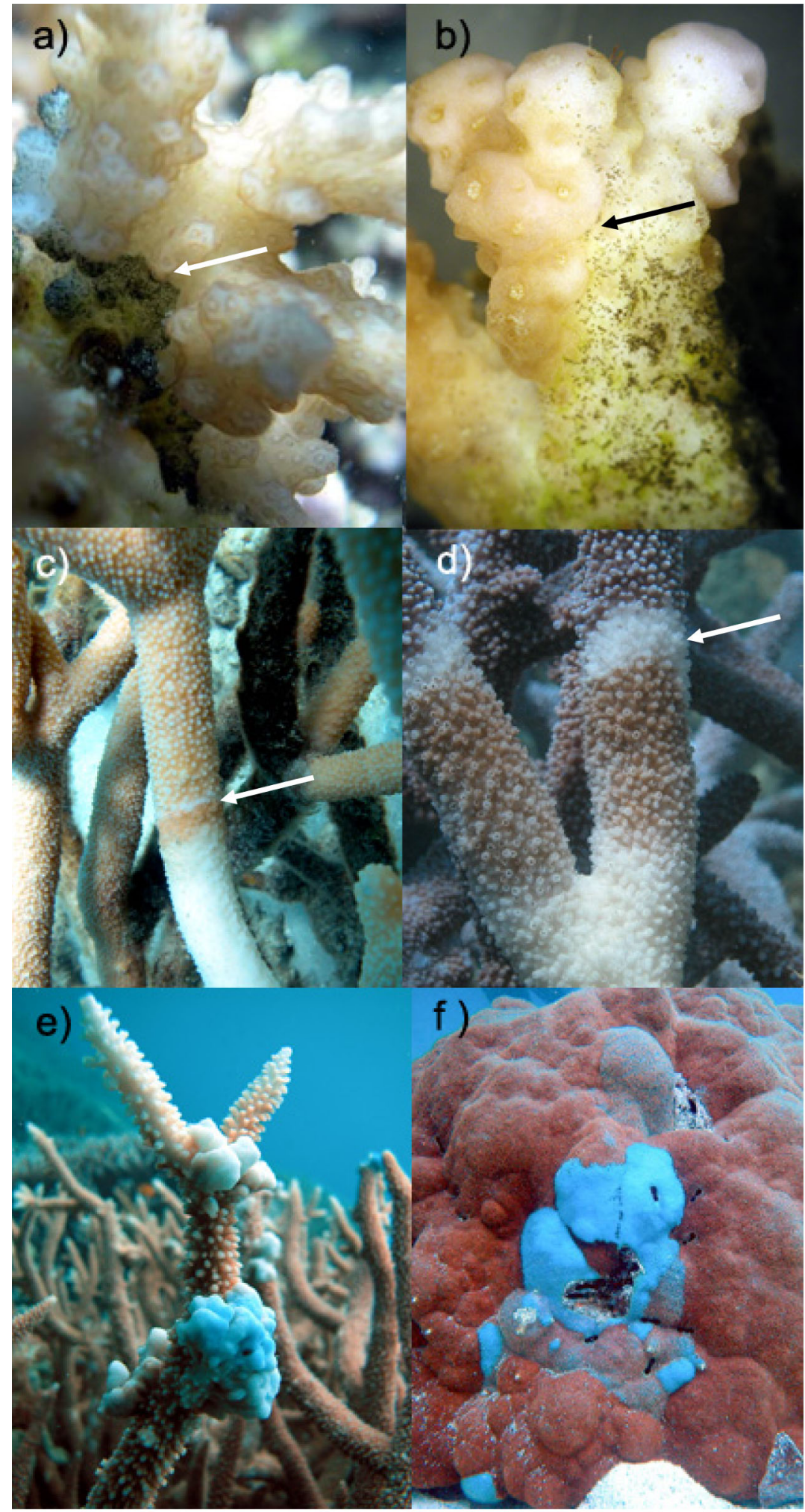

Fig. 2. Macroscopic field signs of skeletal eroding band on (a) Pocillopora damicornis and (b) Acropora sarmentosa; (c,d) brown band disease on Acropora spp.; and growth anomalies on (e) Acropora sp. and (f) Porites sp. Arrows show the location of disease fronts and tissue loss on colonies with skeletal eroding band and brown band disease transects using the line intercept method (Marsh et al. 1984), where the cover of all benthos directly under the central transect line was recorded to the nearest $\mathrm{cm}$. Scleractinian family richness was calculated as the number of scleractinian families present per transect.

The effectiveness of the MPAs in protecting fish stocks from exploitation was assessed by measuring the abundance, size and biomass of 21 species of fish highly valued and targeted by fishers in Palau (Siganus lineatus, S. argenteus, S. canaliculatus, Naso lituratus, Lethrinus olivaceus, L. obsoletus, L. xanthochilus, Lutjanus bohar, Lutjanus gibbus, Caranx ignobilis, C. melampygus, Cetoscarus spp., Hipposcarus longiceps, Valamugil seheli, Liza vaigiensis, Bolbometopon muricatum, Plectropomus areolatus, P. leopardus, P. laevis, Epinephelus fuscoguttatus, E. microdon). Individual sizes and counts of each targeted fish species were determined from surveys of five $50 \times 5 \mathrm{~m}$ belt transects for each MPA and control reef. Only 1 site in each MPA and control reef was surveyed due to the considerably larger area covered in fish surveys $\left(500 \mathrm{~m}^{2}\right.$ at 1 site) compared to coral disease surveys $\left(240 \mathrm{~m}^{2}\right.$ from 2 sites combined). Biomass per fish species was calculated using standard species-specific length-biomass calculations from FishBase (www.fishbase.org, version 02/2006). Total biomass of targeted fish species per transect was then calculated by summing the biomass of all targeted fish species recorded from each transect. The richness of targeted fish species was calculated as the number of targeted species present per transect.

Statistical analysis. Using analysis of variance (ANOVA), we tested for differences in (1) prevalence of diseases individually and pooled; (2) prevalence of bleaching and compromised coral health within acroporid and pocilloporid corals; and (3) other proxies of coral community health (cover and density of scleractinian corals, scleractinian family richness 
and the cover of acroporid and poritid corals combined) as a function of the following factors: (1) MPA status (fixed factor), (2) the 4 Palauan regions (fixed); and (3) 2 replicate sites sampled within each MPA and control reef (random). When significant differences in group means were identified, post hoc Fisher-LSD tests were used to identify group differences. Data were transformed where necessary to fulfil or approximate ANOVA assumptions of normality of distributions and homogeneity of variances.

The 21 targeted fish species were surveyed at only 1 MPA and 1 control site within each of the 4 Palauan regions. Thus, $t$-tests were used to compare the richness of fish species and the abundance, biomass and size of fish between each MPA/non-MPA site pair. Fish species were pooled for analyses of biomass and size. Where sufficient counts per fish taxon were recorded from within both the MPA and non-MPA site within a region, differences in the biomass and size of individuals between MPA and non-MPA sites within these taxa were also tested for using $t$-tests.

To identify variables associated with the prevalence of diseases both pooled and individually, independent of MPA status and region, bivariate regression analyses were performed between all variables measuring coral and fish assemblage health and the disease data. Data were averaged to reef level for these analyses. Only those variables significant at $\alpha=0.05$ are presented. Where more than one variable showed a significant association with the disease data, the contribution of each variable to variation in the disease data was examined using forward selection stepwise regressions.

\section{RESULTS}

Diseased corals were widespread in our surveys of Palaun reefs, being recorded from all regions, all sites and all but 3 of the 48 transects surveyed. Disease prevalence was low, affecting on average $( \pm$ SE) $2.1 \pm$ $0.3 \%$ of acroporid and poritid corals per transect, but up to a maximum of $8.2 \%$ of colonies. At least 8 diseases were identified: black band disease, other cyanobacterial infections, BrB, atramentous necrosis, GAs, Porites ulcerative white spot disease, SEB, and white syndrome. SEB, BrB and GAs were the 3 most commonly recorded diseases, accounting for $\sim 90 \%$ of all diseases cases $(\mathrm{n}=443)$. SEB was the most prevalent disease, affecting $0.88 \pm 0.2 \%$ of acroporid and poritid colonies. BrB affected $0.68 \pm 0.3 \%$ and GAs 0.29 $\pm 0.1 \%$ of acroporid and poritid colonies combined. On average, $0.08 \pm 0.05 \%$ of acroporid and poritid corals were bleached, and $7.1 \pm 0.8 \%$ of colonies showed signs of their health having been compromised by factors other than disease or bleaching.

\section{Influence of MPAs on coral health}

Overall, the prevalence of pooled diseases did not vary significantly between MPA and non-MPA reefs in Palau (Tables 2 \& 3, Fig. 3a). However, patterns in the pooled prevalence of diseases between MPA and nonMPA reefs varied between regions $\left(\mathrm{ANOVA}_{(\mathrm{Region} \times \mathrm{Sta}-}\right.$ tus) $: p=0.014 ;$ Fig. 3a), reflecting the 4 -fold higher disease prevalence within the Cemetery MPA (LSD test: $p$ $<0.01$ ), but conversely, the more than 4 -fold lower prevalence of diseased corals in the Ngemelis MPA (LSD test: $p=0.03$; Fig. 3a). The prevalence of SEB was over 2-fold higher within MPAs than on non-MPA reefs (Tables $2 \& 3$, Fig. 3b), reflecting the greater than 5 -fold higher prevalence of SEB within the Cemetery MPA than in the paired non-MPA reef (LSD test: $\mathrm{p}<$ 0.001; Table 2). The prevalence of BrB and GAs did not vary significantly between MPA and non-MPA reefs in Palau (Tables 2 \& 3, Fig. 3c,d).

Bleaching prevalence did not differ significantly between MPA and control reefs $(p=0.831$, Tables $2 \&$ 3, Fig. 3e). Patterns for the compromised health category varied between regions $\left(\right.$ ANOVA $_{(\text {Region } \times \text { Status) }}: p<$ 0.001; Fig. 3f), reflecting the almost 2 -fold lower prevalence of corals with signs of compromised health within the Bital Rirs MPA (LSD test: $\mathrm{p}<0.01$ ), but conversely, the more than double prevalence of corals with these signs in the Ngleukes MPA (LSD test: $\mathrm{p}<$ 0.001 ), when coral assemblages in these 2 MPA reefs were compared to those in their respective control reefs (Fig. 3f).

\section{Measures of MPA effectiveness}

Overall, percent cover of scleractinian corals did not differ significantly between protected and non-protected reefs (Tables $2 \&$ 3, Fig. 4a). However, in 1 region (Bital Rirs), both the cover of scleractinian corals and the cover of families that are major hosts for coral diseases (Acroporidae and Poritidae) were lower in the MPA compared to the paired control reef (LSD; $p$ $<0.05$; Fig. $4 a, b)$. In contrast, these measures of cover were higher in the Cemetery MPA compared to the paired control reef (LSD test: $p<0.05$; Fig. $4 a$,b). Densities of scleractinian corals did not differ between MPA and control reefs (Tables $2 \& 3$, Fig. 4c). Scleractinian family richness was significantly lower within MPAs than on non-protected reefs (Tables $2 \& 3$, Fig. 4d), particularly within 2 MPAs (Ngelukes, LSD test: $\mathrm{p}<0.001$; Cemetery, LSD test: $\mathrm{p}<0.001)$.

Patterns in species richness of reef fish assemblages targeted by fishers in Palau within and outside of MPAs varied across the 4 regions $\left(\operatorname{ANOVA}_{(\text {Region } \times \text { Status): }}\right.$ : $p=0.015$, Table 2). Although there was no difference 
Table 2. Univariate ANOVA comparing measures of coral health (prevalence of pooled diseases and skeletal eroding band, brown band disease and growth anomalies individually, prevalence of bleaching and signs of other factors that compromise health) and measures of MPA effectiveness (cover of each of scleractinian and Acroporidae and Poritidae corals combined, scleractinian coral density and family richness, as well as species richness, abundance, size and biomass of all fish species pooled) in MPAs and control reefs within 4 Palauan regions (Ngelukes, Cemetery, Bital Rirs, Ngemelis). ${ }^{*}$ Significance at $\alpha=0.05$

\begin{tabular}{|c|c|c|c|c|c|c|c|}
\hline Source of variation & $\mathrm{df}$ & $F$ & $\mathrm{p}$ & Source of variation & df & $F$ & $\mathrm{p}$ \\
\hline \multicolumn{4}{|c|}{ Disease prevalence (\%, sqrt transformed) } & \multicolumn{4}{|c|}{ Acroporidae and Poritidae coral cover (\%) } \\
\hline Status & 1 & 0.72 & 0.420 & Status & 1 & 0.02 & 0.904 \\
\hline Region & 3 & 7.74 & $0.009^{*}$ & Region & 3 & 3.26 & 0.081 \\
\hline Region $\times$ Status & 3 & 6.76 & $0.014^{*}$ & Region $\times$ Status & 3 & 1.70 & 0.244 \\
\hline Site $($ Region $\times$ Status $)$ & 8 & 0.69 & 0.690 & Site(Region $\times$ Status $)$ & 8 & 6.51 & $<0.001^{*}$ \\
\hline \multicolumn{4}{|c|}{ Skeletal eroding band prevalence ( $\%$, sqrt transformed) } & \multicolumn{4}{|c|}{ Scleractinian coral density (colonies $\mathrm{m}^{-2}$ ) } \\
\hline Status & 1 & 8.25 & $0.021^{*}$ & Status & 1 & 1.69 & 0.230 \\
\hline Region & 3 & 14.99 & $0.001^{*}$ & Region & 3 & 9.85 & $0.005^{*}$ \\
\hline Region $\times$ Status & 3 & 9.25 & $0.006^{*}$ & Region $\times$ Status & 3 & 2.88 & 0.103 \\
\hline Site(Region $\times$ Status $)$ & 8 & 0.27 & 0.971 & Site $($ Region $\times$ Status $)$ & 8 & 0.48 & 0.861 \\
\hline \multicolumn{4}{|c|}{ Brown band prevalence ( $\%$, sqrt transformed) } & \multirow{2}{*}{\multicolumn{4}{|c|}{$\begin{array}{l}\text { Scleractinian family richness } \\
\text { (species per transect, } \log _{10} \text { transformed data) }\end{array}$}} \\
\hline Status & 1 & 0.41 & 0.540 & & & & \\
\hline Region & 3 & 23.92 & $<0.001^{*}$ & Status & 1 & 9.51 & $0.006^{*}$ \\
\hline Region $\times$ Status & 3 & 0.36 & 0.784 & Region & 3 & 35.32 & $<0.001^{*}$ \\
\hline Site $($ Region $\times$ Status $)$ & 8 & 0.34 & 0.943 & Region $\times$ Status & 3 & 5.61 & $0.008^{*}$ \\
\hline \multicolumn{4}{|c|}{ Growth anomaly prevalence (\%, sqrt transformed) } & Site $($ Region $\times$ Status $)$ & 8 & 0.57 & 0.619 \\
\hline Status & 1 & 0.43 & 0.530 & \multicolumn{4}{|c|}{ Fish species richness (species per transect) } \\
\hline Region & 3 & 0.81 & 0.522 & Status & 1 & 2.30 & 0.139 \\
\hline Region $\times$ Status & 3 & 2.83 & 0.106 & Region & 3 & 1.39 & 0.263 \\
\hline Site $($ Region $\times$ Status $)$ & 8 & 0.71 & 0.677 & Region $\times$ Status & 3 & 4.04 & $0.015^{*}$ \\
\hline \multicolumn{4}{|c|}{ Bleaching prevalence $\left(\%, \log _{10}+0.1\right.$ transformed $)$} & \multirow{2}{*}{\multicolumn{4}{|c|}{$\begin{array}{l}\text { Fish abundance } \\
\text { (number per transect, } \log _{10}+0.001 \text { transformed) }\end{array}$}} \\
\hline Status & 1 & 0.05 & 0.831 & & & & \\
\hline $\begin{array}{l}\text { Region } \\
\text { Region } \times \text { Status }\end{array}$ & $\begin{array}{l}3 \\
3\end{array}$ & $\begin{array}{l}1.55 \\
0.30\end{array}$ & $\begin{array}{l}0.2+5 \\
0.824\end{array}$ & Status & 1 & 0.08 & 0.617 \\
\hline Site $($ Region $\times$ Status $)$ & 8 & 1 & 0.455 & Region & 3 & 2.14 & 0.114 \\
\hline \multicolumn{4}{|c|}{ Compromised prevalence (\%, sqrt transformed) } & Region $\times$ Status & 3 & 0.91 & 0.455 \\
\hline Status & 1 & 0.06 & 0.807 & Fish size $(\mathrm{cm})$ & & & \\
\hline Region & 3 & 32.22 & $<0.001^{*}$ & Status & 1 & 15.10 & $0.001^{*}$ \\
\hline Region $\times$ Status & 8 & 9.46 & $0.005^{*}$ & Region & 3 & 0.16 & 0.925 \\
\hline Site $($ Region $\times$ Status $)$ & 8 & 0.21 & 0.987 & Region $\times$ Status & 3 & 7.79 & $0.001^{*}$ \\
\hline \multicolumn{4}{|c|}{ Scleractinian coral cover $(\%)$} & \multirow{2}{*}{\multicolumn{4}{|c|}{$\begin{array}{l}\text { Fish biomass } \\
\text { (grams per transect, } \log _{10}+0.001 \text { transformed) }\end{array}$}} \\
\hline Status & 1 & 0.05 & 0.825 & & & & \\
\hline Region & 3 & 3.96 & 0.053 & Status & 1 & 2.34 & 0.136 \\
\hline Region $\times$ Status & 3 & 2.04 & 0.187 & Region & 3 & 0.37 & 0.778 \\
\hline Site $($ Region $\times$ Status $)$ & 8 & 4.68 & $0.001^{*}$ & Region $\times$ Status & 3 & 1.70 & 0.188 \\
\hline
\end{tabular}

in species richness between protected and non-protected reefs overall (Tables 2 \& 3), a trend for increased species richness of targeted reef fish within MPAs was driven by significantly higher species richness within MPAs for the Cemetery and Ngelukes regions (Cemetery, LSD test: $\mathrm{p}=0.008$; Ngelukes, LSD test: $\mathrm{p}=0.044$; Fig. 5a). On average, over twice as many species were recorded from transects within the Cemetery MPA compared to its paired control reef (Fig. 5a), and 1.6 times as many species were recorded from transects within the Ngelukes MPA (Fig. 5a). Similarly, the abundance of targeted reef fish was not enhanced within MPAs (Tables 2 \& 3, Fig. 5b). However, fish were larger inside MPAs when reefs were combined for all 4 regions (Tables $2 \& 3$, Fig. 5c), but most notably within 2 regions (Cemetery, LSD test: $p<0.001$;
Ngelukes, LSD test: $\mathrm{p}<0.05)$. Fish were on average twice as large inside the Cemetery MPA compared to the paired control reef (Fig. 5c). Overall, fish biomass was not greater inside MPAs when reefs were combined for all 4 regions (Tables 2 \& 3, Fig. 5d), despite biomass being 3.5 times greater within the Ngelukes MPA compared to its paired control reef (LSD test: $\mathrm{p}<$ 0.05; Fig. 5d).

For 2 of the 7 targeted fish species, fish were larger and populations were higher in biomass within at least 1 MPA compared to its paired control reef. Scarus spp. and Lutjanus gibbus were greater in size and biomass within the Ngelukes MPA, and Scarus spp. were also significantly larger in the Bital Rirs MPA (Table 4). In contrast, Siganus argenteus individuals were smaller in size and biomass inside both the Bital Rirs and 
Table 3. Mean ( \pm SE) values recorded for measures of coral health (prevalence of pooled diseases and skeletal eroding band, brown band disease and growth anomalies individually, prevalence of bleaching and signs of other factors that compromise health) and measures of MPA effectiveness (cover of each of scleractinian and Acroporidae and Poritidae corals combined, scleractinian coral density and family richness, as well as species richness, abundance, size and biomass of targeted fish species pooled) for MPA and control reefs pooled. * Significant differences in values between MPA and control reefs, $\alpha=0.05$

\begin{tabular}{|c|c|c|}
\hline Measure & MPA & Control \\
\hline Disease ( $\%$ of corals) & $2.29 \pm 0.45$ & $1.83 \pm 0.44$ \\
\hline Skeletal eroding band ( $\%$ of corals) ${ }^{*}$ & $1.23 \pm 0.37$ & $0.53 \pm 0.11$ \\
\hline Brown band (\% of corals) & $0.59 \pm 0.28$ & $0.7 \pm 0.4$ \\
\hline Growth anomalies (\% of corals) & $0.18 \pm 0.07$ & $0.4 \pm 0.2$ \\
\hline Bleaching ( $\%$ of corals) & $0.06 \pm 0.04$ & $0.09 \pm 0.01$ \\
\hline Compromised (\% of corals) & $7.12 \pm 0.95$ & $7.08 \pm 1.22$ \\
\hline Scleractinian coral cover (\% cover) & $46.4 \pm 4.5$ & $48.3 \pm 5.2$ \\
\hline Acroporidae and Poritidae cover (\% cover) & $41.1 \pm 5$ & $41.5 \pm 5.6$ \\
\hline Scleractinian coral density (colonies $\mathrm{m}^{-2}$ ) & $16.2 \pm 1.3$ & $17.7 \pm 1.4$ \\
\hline Scleractinian family richness (families per transect) * & $8.25 \pm 0.49$ & $9.33 \pm 3.99$ \\
\hline Fish species richness (species per transect) & $4.1 \pm 0.29$ & $3.45 \pm 0.38$ \\
\hline Fish abundance (number) & $36.85 \pm 9.43$ & $38.1 \pm 7.33$ \\
\hline Fish size (length, $\mathrm{cm}$ ) ${ }^{*}$ & $23.05 \pm 1.08$ & $17.96 \pm 1.19$ \\
\hline Fish biomass (grams per transect) & $16291.13 \pm 4837.7$ & $9537.31 \pm 1589$ \\
\hline
\end{tabular}

Ngemelis MPAs compared to their respective paired control reefs. The other 4 species (Naso lituratus, Plectropomus areolatus, Hipposcarus longiceps, Cetoscarus bicolor) did not differ significantly in either size or biomass between MPA and control reefs.

\section{Regional variation in coral health and coral and fish assemblages}

The regional location of a reef significantly affected the pooled disease prevalence (Table 2, Fig. 3a), the prevalence of SEB and BrB individually (Fig. 3b,c), as well as the prevalence of compromised corals (Table 2, Fig. 3f). The prevalence of growth anomalies and bleaching did not vary among the 4 studied regions of Palau (Table 2, Fig. 3d,e). The prevalence of pooled diseases was lowest in the southernmost Ngemelis region and highest in the Bital Rirs region (Table 2, Fig. 3a), reflecting the low prevalence of SEB and the absence of BrB in the Ngemelis region (Fig. 3b,c). BrB prevalence was highest in the Bital Rirs region, and SEB prevalence was highest in the Cemetery region (Fig. 3b,c). The prevalence of corals with signs of compromised health was significantly higher within the Bital Rirs region than in the Cemetery region (LSD test: $\mathrm{p}<0.05$; Fig. 3f). In the Ngemelis region, where disease prevalence was lowest (Fig. 3a), the density of scleractinian colonies was highest (LSD test: $\mathrm{p}<0.05$; Fig. 4c), and the cover of scleractinian corals, as well as acroporid and poritid corals, the families most susceptible to disease, was lowest on Ngemelis reefs (and also in the Ngelukes reef region; LSD test: $p<0.05$; Fig. $4 a, b)$. The high richness of scleractinian families in the Ngemelis region (Fig. 4d) supports regional patterns for other measures of overall coral health (high scleractinian density, low disease prevalence), although the similarly high family richness in the Bital Rirs region does not (all LSD tests: $\mathrm{p}<0.05$; Fig. 4d). All measures of fish community health assessed in this study (abundance, richness of targeted species, mean size and biomass) showed no regional variability (Fig. 5).

\section{Other factors influencing coral disease prevalence}

Bivariate regressions revealed that pooled disease prevalence in acroporid and poritid corals was moderately positively correlated with the cover of these families $\left(F=9.47, \mathrm{r}^{2}=0.61, \mathrm{p}=0.022\right.$; Fig. 6a) and more weakly negatively correlated with the species richness of targeted fish $\left(F=6.19, \mathrm{r}^{2}=0.51, \mathrm{p}=0.047\right.$; Fig. $\left.6 \mathrm{~b}\right)$. All other variables showed no significant association with the prevalence of diseases pooled. Stepwise regression indicated that fish species richness did not increase the predictive ability of a model including only the cover of acroporid and poritid corals (Table 5). We also found a strong negative association between the prevalence of SEB and the species richness of targeted reef fish $\left(F=55.72, \mathrm{r}^{2}=0.90, \mathrm{p}<0.001\right.$; Fig. $\left.6 \mathrm{c}\right)$, and a more moderate positive association between SEB prevalence and the cover of acroporid and poritid corals $\left(F=6.95, \mathrm{r}^{2}=0.54, \mathrm{p}=0.039\right.$; Fig. $\left.6 \mathrm{~d}\right)$, with all other variables showing no significant association. Stepwise regression indicated that the cover of acroporid and poritid corals did not increase the predictive ability of a model including only the richness of tar- 
(a) Diseases pooled

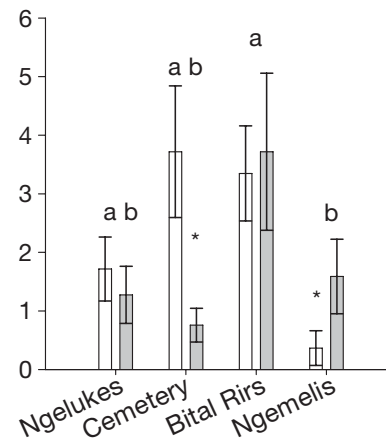

(c) Brown band disease

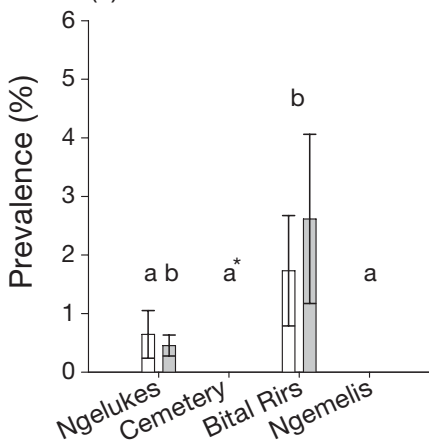

(e) Bleached

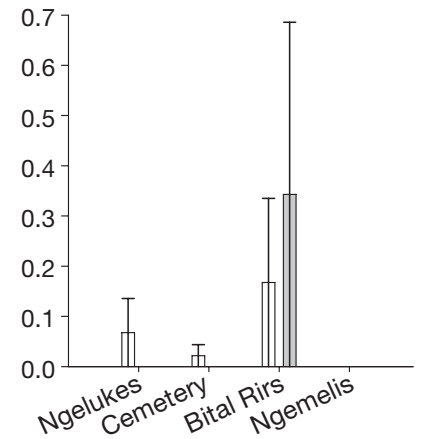

Region (b) Skeletal eroding band

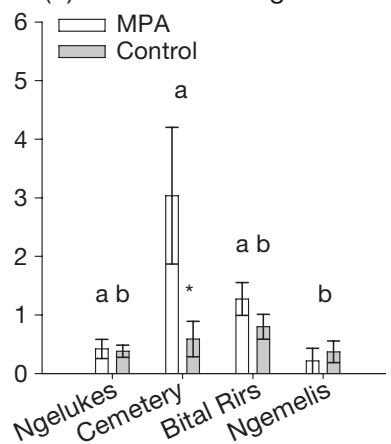

(d) Growth anomalies

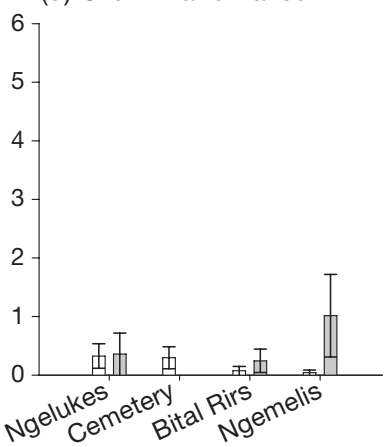

(f) Compromised

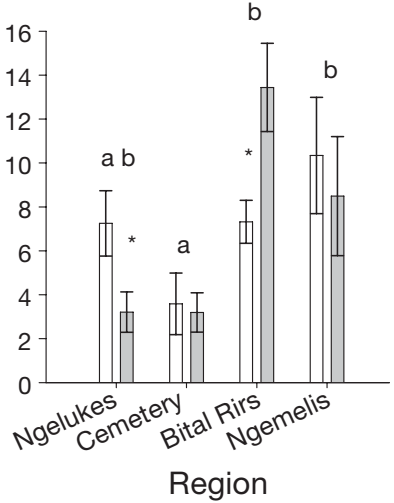

Fig. 3. Mean \pm SE prevalence of (a) diseases pooled, (b) skeletal eroding band, (c) brown band disease, (d) growth anomalies, (e) bleaching and (f) compromised health in acroporid and poritid corals within MPAs and control reefs in 4 Palauan regions (Ngelukes, Cemetery, Bital Rirs and Ngemelis). * Significant difference between MPA and control reefs at $\alpha=0.05$; lowercase letters indicate homogenous regional groupings as indicated by Fisher LSD post hoc tests

geted fish species, which explained $90 \%$ of the variation in SEB prevalence among reefs (Table 6). The prevalence of $\mathrm{BrB}$ was strongly positively correlated with the prevalence of bleached colonies $\left(F=106.95, \mathrm{r}^{2}\right.$ $=0.95, \mathrm{p}<0.001$; Fig. 6e), with all other variables showing no significant association. None of the variables tested was significantly associated with the prevalence of GAs.

(a) Scleractinian cover

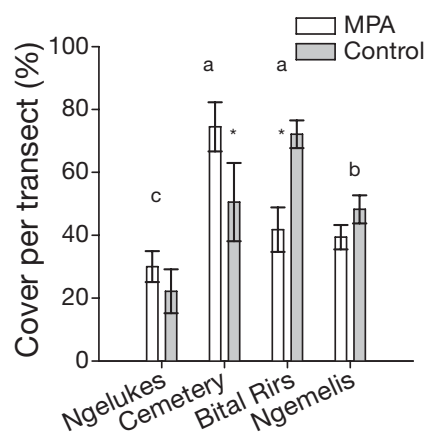

(c) Scleractinan density

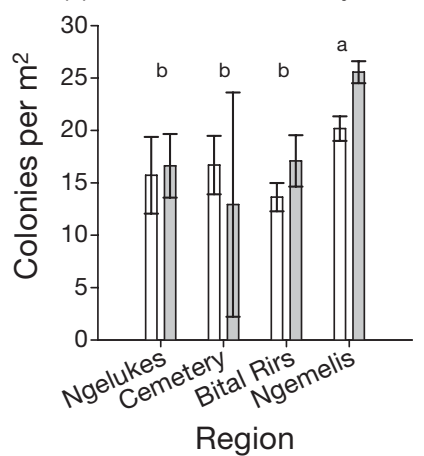

(b) Combined Acroporidae and Poritidae cover

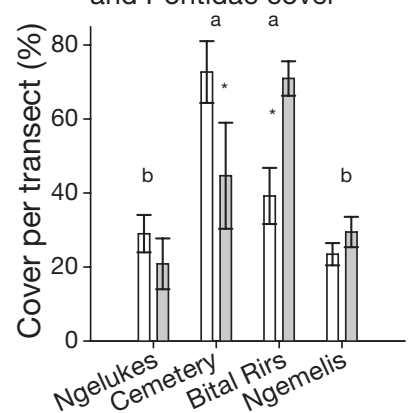

(d) Scleractinian family richness

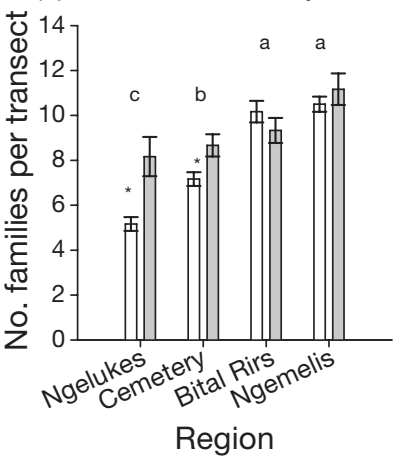

Fig. 4. Variability in mean \pm SE (a) scleractinian coral cover, (b) combined cover of the families Acroporidae and Poritidae, (c) scleractinian coral density and (d) scleractinian family richness between MPA and control reef pairs in 4 Palauan regions (Ngelukes, Cemetery, Bital Rirs and Ngemelis). ${ }^{*}$ Significant difference between MPA and control pair at $\alpha=0.05$; lowercase letters indicate homogenous regional groupings as indicated by Fisher LSD post hoc tests

\section{DISCUSSION}

We found little evidence that MPAs enhance the health of acroporid and poritid assemblages in Palau. Overall, we found no difference in the prevalence of either the diseases pooled, or GAs and BrB individually, between MPAs and non-protected reefs. We also found no differences in the prevalence of bleaching and signs of other factors that compromise coral health in poritid and acroporid corals between MPAs and non-protected reefs. Results of this study therefore partially corroborate those of previous studies, which found that the prevalence of GAs on Kenyan reefs in the western Indo-Pacific (McClanahan et al. 2008) and the prevalence of several diseases on Little Cayman Island in the Caribbean (Coelho \& Manfrino 2007) were not reduced inside MPAs. In fact, the prevalence of SEB was 2-fold higher within MPAs than on non-protected reefs in Palau. When protected and non-protected reef pairs were analysed individually, in some cases, measures of coral health were significantly worse inside the studied 

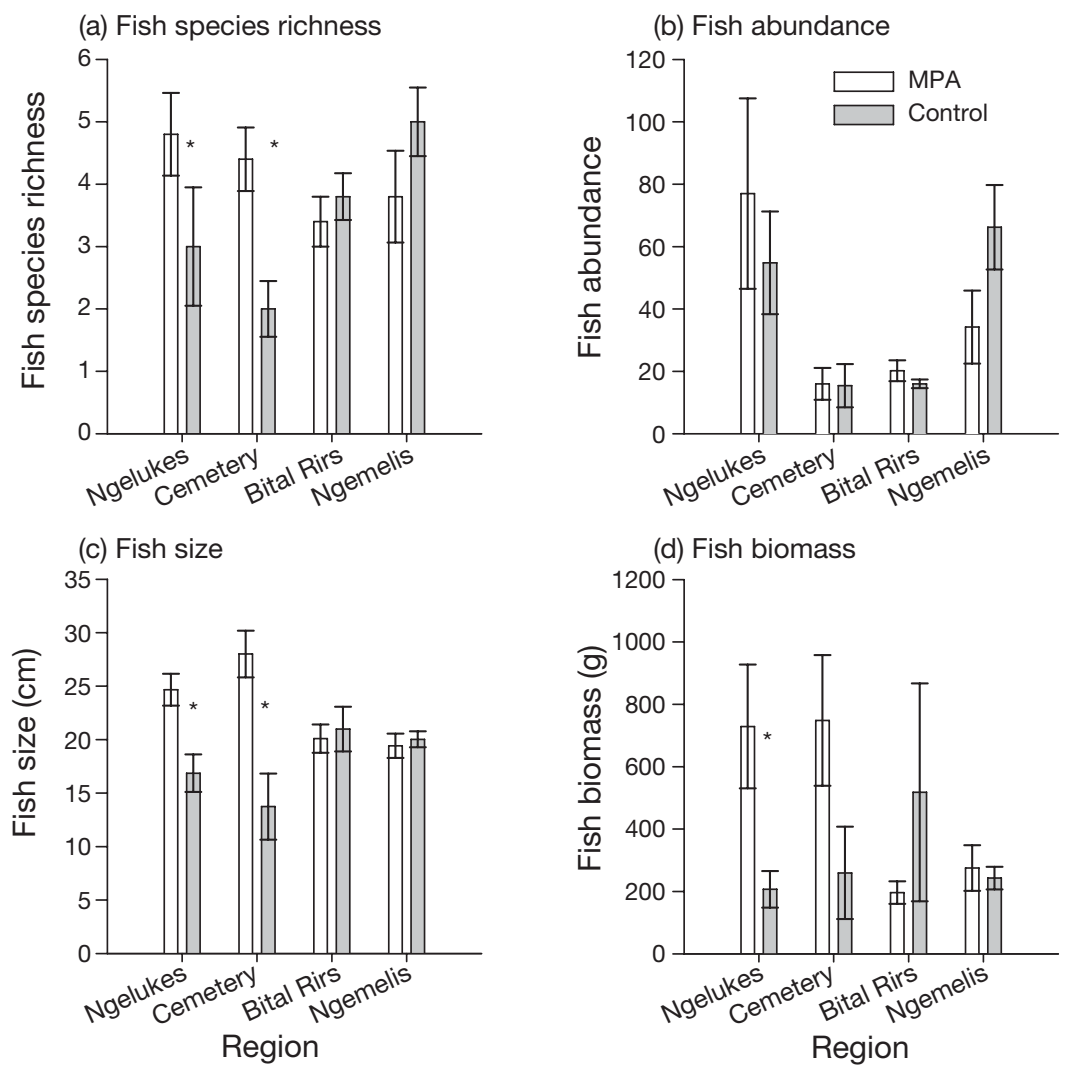

Fig. 5. Variability in mean \pm SE fish (a) species richness, (b) abundance, (c) size and (d) biomass per transect between MPA and control reef pairs in 4 Palauan regions (Ngelukes, Cemetery, Bital Rirs and Ngemelis). ${ }^{*}$ Significant difference between MPA and control pair at $\alpha=0.05$; lowercase letters indicate homogenous regional groupings as indicated by Fisher LSD post hoc tests

Table 4. Results of $t$-tests comparing the average size and biomass of fish taxa in MPAs and paired control reefs within regions of Palau. Data only shown for taxa and regions for which taxa were sufficiently abundant to allow comparisons. Size: average size of fish per transect; biomass: grams per transect. *Significance at $\alpha=0.05$. Biomass data were $\left(\log _{10}+0.001\right)$ transformed

\begin{tabular}{|c|c|c|c|c|c|c|c|c|}
\hline Species & Region & Measure & $t$ & df & $\mathrm{p}$ & $\begin{array}{c}\text { MPA/Control } \\
\text { difference? }\end{array}$ & $\begin{array}{c}\text { MPA } \\
(\text { mean } \pm \text { SE) }\end{array}$ & $\begin{array}{c}\text { Control } \\
(\text { Mean } \pm \text { SE) }\end{array}$ \\
\hline \multirow[t]{4}{*}{ Siganus argenteus } & \multirow[t]{2}{*}{ Bital Rirs } & Size & 2.568 & 18 & $0.019^{*}$ & Control > MPA & $15 \pm 1.54$ & $19.92 \pm 1.13$ \\
\hline & & Biomass & 2.765 & 18 & $0.013^{*}$ & Control > MPA & $72.05 \pm 19.16$ & $154.54 \pm 26.02$ \\
\hline & \multirow[t]{2}{*}{ Ngemelis } & Size & 2.835 & 8.535 & $0.02^{*}$ & Control > MPA & $13.13 \pm 0.91$ & $15.86 \pm 0.3$ \\
\hline & & Biomass & 2.670 & 7.879 & $0.029^{*}$ & Control > MPA & $45.58 \pm 7.75$ & $73.6 \pm 4.29$ \\
\hline \multirow[t]{2}{*}{ Cetoscarus bicolor } & \multirow[t]{2}{*}{ Ngemelis } & Size & 1.357 & 21 & 0.189 & No & $21.13 \pm 2.37$ & $25.56 \pm 1.74$ \\
\hline & & Biomass & 1.26 & 21 & 0.221 & No & $221.39 \pm 83.68$ & $255.73 \pm 63.93$ \\
\hline \multirow[t]{4}{*}{ Lutjanus gibbus } & \multirow[t]{2}{*}{ Ngelukes } & Size & -14.154 & 312.96 & $<0.001^{*}$ & MPA > Control & $23.2 \pm 0.27$ & $16.42 \pm 0.4$ \\
\hline & & Biomass & -12.968 & 264.06 & $<0.001^{*}$ & MPA > Control & $274.62 \pm 6.74$ & $117.76 \pm 8.4$ \\
\hline & \multirow[t]{2}{*}{ Ngemelis } & Size & 0.579 & 55.177 & 0.565 & No & $16.05 \pm 0.5$ & $16.5 \pm 0.47$ \\
\hline & & Biomass & 1.5 & 68.689 & 0.138 & No & $86.13 \pm 7.29$ & $102.88 \pm 8.5$ \\
\hline \multirow[t]{2}{*}{ Hipposcarus longiceps } & \multirow[t]{2}{*}{ Ngemelis } & Size & -1.913 & 21 & 0.069 & No & $27.42 \pm 1.83$ & $22.27 \pm 1.83$ \\
\hline & & Biomass & -1.746 & 21 & 0.095 & No & $1313.38 \pm 222.8$ & $705.36 \pm 165.69$ \\
\hline \multirow[t]{4}{*}{ Scarus spp. } & \multirow[t]{2}{*}{ Ngelukes } & Size & -6.394 & 105 & $<0.001^{*}$ & MPA > Control & $22.62 \pm 0.65$ & $16.25 \pm 0.75$ \\
\hline & & Biomass & -6.497 & 105 & $<0.001^{*}$ & MPA > Control & $289.58 \pm 20.62$ & $122.27 \pm 16.17$ \\
\hline & \multirow[t]{2}{*}{ Bital Rirs } & Size & -2.127 & 91.325 & $0.036^{*}$ & MPA > Control & $18.81 \pm 0.61$ & $17.24 \pm 0.43$ \\
\hline & & Biomass & -1.975 & 94.04 & 0.051 & No & $173.68 \pm 19.06$ & $123.22 \pm 10.18$ \\
\hline \multirow[t]{2}{*}{ Plectropomus areolatus } & \multirow[t]{2}{*}{ Bital Rirs } & Size & 0.936 & 24 & 0.359 & No & $21.61 \pm 1.93$ & $25 \pm 3.58$ \\
\hline & & Biomass & 0.826 & 24 & 0.417 & No & $200.39 \pm 46.3$ & $327.46 \pm 117.92$ \\
\hline \multirow[t]{2}{*}{ Naso lituratus } & \multirow[t]{2}{*}{ Ngemelis } & Size & -0.683 & 79 & 0.497 & No & $17.74 \pm 0.85$ & $16.98 \pm 0.73$ \\
\hline & & Biomass & -0.747 & 79 & 0.458 & No & $217.29 \pm 34.73$ & $185.88 \pm 21.64$ \\
\hline
\end{tabular}



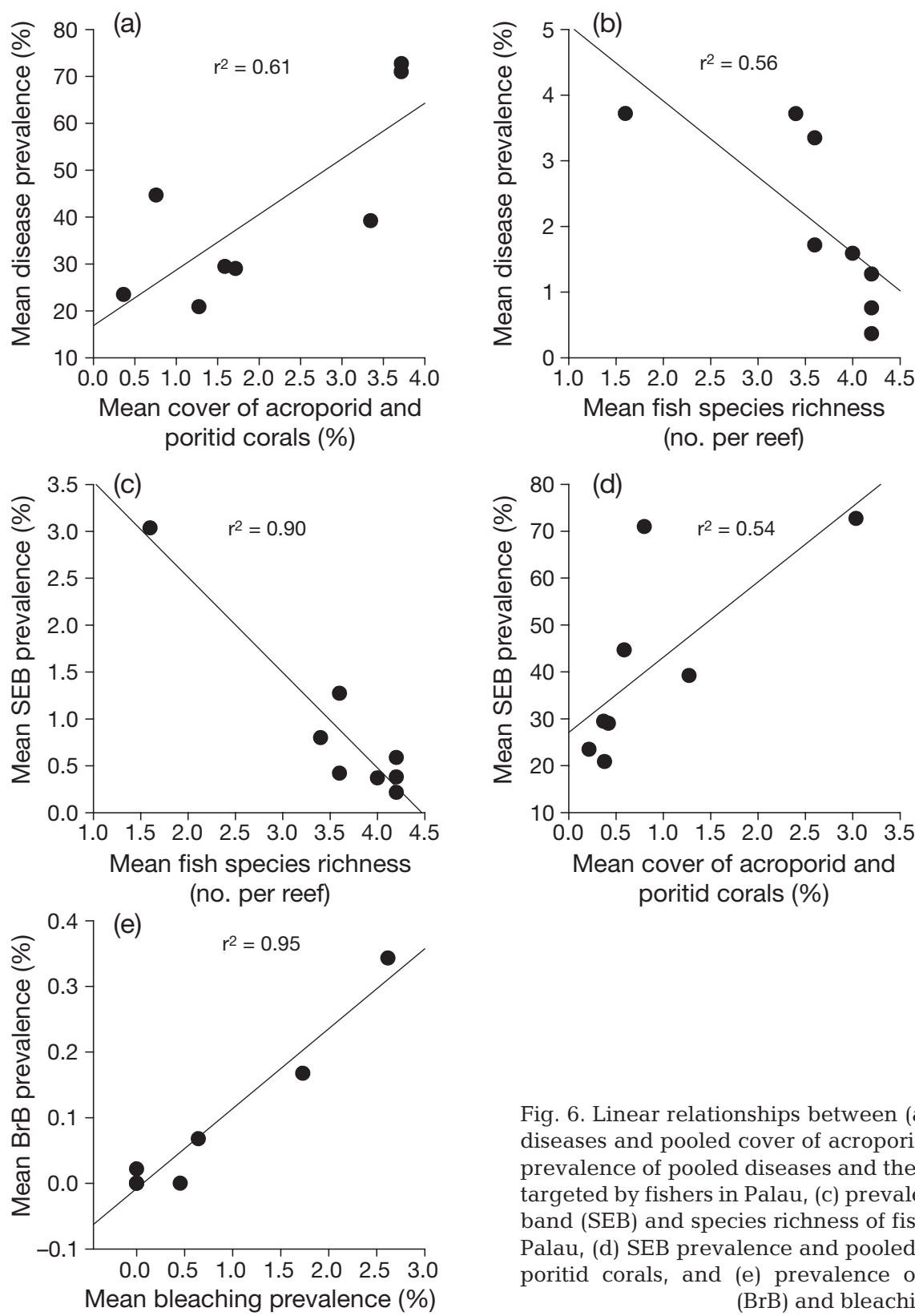

Fig. 6. Linear relationships between (a) prevalence of pooled diseases and pooled cover of acroporid and poritid corals, (b) prevalence of pooled diseases and the species richness of fish targeted by fishers in Palau, (c) prevalence of skeletal eroding band (SEB) and species richness of fish targeted by fishers in Palau, (d) SEB prevalence and pooled cover of acroporid and poritid corals, and (e) prevalence of brown band disease $(\mathrm{BrB})$ and bleaching

MPAs. The prevalence of pooled diseases and SEB individually were significantly greater inside the Cemetery MPA, and the prevalence of corals having compromised health was greater within the Ngelukes MPA, than within paired control sites. However, the effects of MPAs on coral health were variable, since the prevalence of pooled diseases was lower within the Ngemelis MPA, and colonies with signs of compromised health were less prevalent within the Bital Rirs MPA than within paired control sites. There are at least 2 possible explanations for the inconsistent patterns in the relationship between MPA status and coral health: either factors affecting coral health are not governed by the protection status afforded by MPAs, for example

water flow and oceanographic parameters, or the studied MPAs were not functional in protecting reefs from activities that affect coral health.

Contrary to predictions for well-managed MPAs (reviewed by Russ 2002), none of the 4 measures of fish stock health (species richness, abundance, size and biomass) was enhanced within 2 of the MPAs studied (Ngemelis and Bital Rirs), suggesting that these 2 MPAs were not effective in enhancing fish stocks. In contrast, 1.6- to 2.2-fold increases in the species richness of fish detected in the Ngelukes and Cemetery MPAs, respectively, are consistent with higher rates of compliance, and fish feeding within the Cemetery MPA, despite their more recent establishment as MPAs 
Table 5. Results of stepwise forward regression $\left(F=9.47, \mathrm{r}^{2}=\right.$ $0.61, \mathrm{p}=0.022$ ) with fish species richness and the cover of acroporid and poritid corals as the regressors with the prevalence of diseases pooled. Only the 2 variables found to be positively associated with the prevalence of diseases pooled (fish species richness and cover of acroporid and poritid corals) were entered into the regression model. ${ }^{*}$ Significance at $\alpha=0.05$. VIF: variance inflation factors

\begin{tabular}{|lccc|}
\hline & VIF & $t$-ratio & $\mathrm{p}$ \\
\hline $\begin{array}{l}\text { Cover of acroporid and } \\
\text { poritid corals } \\
\text { Fish species richness }\end{array}$ & 1 & 3.077 & $0.022^{*}$ \\
\hline
\end{tabular}

Table 6. Results of stepwise forward regression $\left(F=55.72, \mathrm{r}^{2}=\right.$ $0.903, p<0.001$ ) with fish species richness and the cover of acroporid and poritid corals as the regressors with the prevalence of skeletal eroding band (SEB). Only the 2 variables found to be positively associated with SEB prevalence (fish species richness and cover of acroporid and poritid corals) were only entered into the regression model.

${ }^{*}$ Significance at $\alpha=0.05$. VIF: variance inflation factors

\begin{tabular}{|lccc|}
\hline & VIF & $t$-ratio & $\mathrm{p}$ \\
\hline $\begin{array}{l}\text { Fish species richness } \\
\begin{array}{l}\text { Cover of acroporid and } \\
\text { poritid corals }\end{array}\end{array}$ & 1 & 9.041 & $<0.001^{*}$ \\
\hline
\end{tabular}

(Table 1). Similarly, 1.5- to 2-fold increases in fish size within the Ngelukes and Cemetery MPAs corroborate our conclusion that these 2 MPAs are more effectively managed. The lack of consistent enhancement in the 4 measures of fish stock health across all 4 MPAs suggests that MPA status was not a good indicator of levels of anthropogenic activities affecting fish stocks, and by extension, the health of coral assemblages in these regions.

A key factor influencing the inconsistency in health measures for reef fish stocks in MPAs is likely the relatively small human population in Palau ( 20 000), and by extension, the relatively low fishing pressure in this region. Low fishing pressure overall is consistent with the lack of difference in fish species richness, fish size or fish biomass between MPAs and non-protected reefs in the Bital Rirs and Ngemelis regions, the latter being the most remote from Palau's population centre. The Ngelukes region is closest to the capital city of Koror (see Fig. 1) and correspondingly, experiences the greatest fishing pressure. Not surprisingly, greater differences in species richness, size and biomass of fish (Scarus spp. and Lutjanus gibbus, as well as all species pooled) were detected between the Ngelukes MPA and its paired control reef, including at least a 3 -fold increase in fish biomass, highlighting the effects of fishing pressure on non-protected reefs in close prox- imity to population centres. Compliance with MPA restrictions, the size and age of MPAs, and inputs of agricultural runoff and natural variation in the composition of coral communities are other factors likely to have contributed to the variable effectiveness of the studied MPAs.

While MPA status did not correlate consistently with health measures for corals or fish, we did find evidence that MPAs which enhance the health of fish stocks might also enhance the health of acroporid and poritid assemblages. The strong negative association between the prevalence of pooled diseases and the species richness of even the limited number of fish species included in this study indicates that well-managed MPAs, by increasing fish species richness, may lower the prevalence of coral disease. The association between disease prevalence and fish species richness was primarily driven by the strong negative association between fish species richness and the prevalence of SEB. Injury is likely to play an important role in the development of SEB (Page \& Willis 2008); thus, the presence of a greater range of fish feeding guilds within MPAs, including predators of corallivorous fish and invertebrates, may ensure that injuries to corals from feeding corallivores are reduced, thereby reducing opportunities for the development of SEB. Similarly, if increased fish species richness results in increases in predators of corallivorous fish or invertebrates, which are the most common vectors of disease (Sussman et al. 2003, Williams \& Miller 2005, Aeby \& Santavy 2006, Dalton \& Godwin 2006), well-managed MPAs could diminish the spread and correspondingly the prevalence of SEB. Increases in fish species richness within MPAs are typically matched by increases in fish biomass (see Russ 2002), and it is therefore surprising that the prevalence of SEB and pooled diseases did not correlate with fish biomass. However, increases in biomass would not be expected to result in this same pattern of decreased SEB prevalence if increases in biomass did not reflect the addition of predators of fish and invertebrate corallivores to fish feeding guilds, and hence reductions in injury to corals.

Well-managed MPAs often increase the species richness of fish communities (reviewed by Halpern 2003); however, fish species richness may be influenced by other factors, including tourism activities, which could also contribute to the greater prevalence of SEB within MPAs in Palau. The greater richness of fish species and size of fish inside the Cemetery MPA were undoubtedly linked to tourists feeding fish within this MPA. Fish fed by humans are typically larger and less afraid of divers and consequently more visible during visual censuses (Kulbicki 1998). Evidence that elevated nutrient levels enhance the frequency and severity of some diseases (Kuta \& Richardson 2002, Bruno et al. 2003, 
Voss \& Richardson 2006, McClanahan et al. 2008) suggests that increases in nutrients via additions of fish food could be responsible for higher levels of SEB in the Cemetery MPA. Experimental studies could provide insights into whether nutrients influence SEB prevalence. Increases in visitation and coral breakage from tourist-associated activities, including boat anchoring and groundings, snorkelling and diving within aesthetically pleasing MPAs, may also increase opportunities for disease development within MPAs, given links between injury and disease development in corals (Bak \& Criens 1981, Antonius \& Riegl 1997, 1998, Page \& Willis 2008). Fish species richness may therefore be a proxy for other factors that were not measured, but nonetheless influence SEB prevalence on the studied reefs.

The cover of disease-susceptible hosts is also likely to play an important role in determining disease levels, given that many diseases are density dependent (Anderson \& May 1979, Bruno et al. 2007). Although the studied MPAs did not enhance the cover of corals, MPAs in other reef regions have been successful in enhancing the abundance or cover of corals (McClanahan \& Muthiga 1988, McClanahan \& Mutere 1994, McClanahan 1997, Williamson et al. 2004). Given that many diseases are density dependent (Anderson and May 1979), the maintenance of high cover of a reduced number of families within MPAs, 2 Palauan MPAs (Ngelukes and Cemetery) having a lower richness of scleractinian families than control sites, could facilitate increases in disease within MPAs. The tradeoff between fish richness as a protective measure against coral disease and increased host cover as a facilitator of some diseases is a complex issue needing more research.

The positive association between the prevalence of $\mathrm{BrB}$ and bleaching on Palauan reefs suggests that the environmental conditions associated with bleaching, most commonly high water temperatures and UV light levels (Brown 1997, Hoegh-Guldberg 1999), increase the virulence of the BrB pathogen and/or the susceptibility of corals to invasion by this pathogen. This hypothesis is supported by evidence that elevated temperatures increase the virulence of other coral pathogens (Kushmaro et al. 1998, Banin et al. 2000, Ben-Haim et al. 2003), while concurrently increasing the susceptibility of coral hosts (Ward et al. 2007), leading to an increased likelihood of disease development in bleached corals (Miller et al. 2006, Muller et al. 2008). Strong associations between the prevalence of bleaching and GAs further support this interpretation (McClanahan et al. 2008). On average, bleaching and $\mathrm{BrB}$ affected less than $1 \%$ of acroporid and poritid corals each on Palauan reefs. However, the positive association between bleaching and $\mathrm{BrB}$ prevalence suggests that BrB prevalence is likely to increase as bleaching increases (Hoegh-Guldberg 1999). Other Indo-Pacific diseases associated with thermal anomalies (Selig et al. 2006, Bruno et al. 2007) or bleaching (McClanahan et al. 2008) are also likely to increase following bleaching events, independently of MPA status. In such scenarios, even very large MPAs are unlikely to provide significant benefits for coral communities and the fish dependent on them (McClanahan et al. 2001, Jones et al. 2004a). Given predictions of increases in the frequency and intensity of bleaching events with climate warming (Hoegh-Guldberg 1999) and increasing evidence of links between bleaching and diseases in corals (Harvell et al. 1999, Miller et al. 2006, Muller et al. 2008, McClanahan et al. 2008), clear strategies to effectively mitigate the impacts of bleaching and subsequent disease epizootics should be considered to minimise losses of corals from Indo-Pacific reefs.

Although the 4 studied MPAs were not effective in reducing diseases already low in prevalence (disease affected on average $\sim 2 \%$ of the 2 most susceptible families, Acroporidae and Poritidae), MPAs may be effective at mitigating disease effects during epizootics. The small number of MPAs examined in this study, and considerable variation in the coral communities and physical settings of reefs in the 4 regions examined, may also have limited our ability to detect the influence of MPAs on coral health. Comparisons of disease prevalence inside and outside of a greater number of MPAs during epizootics may provide greater opportunities to explore the mechanisms by which MPAs influence coral assemblage health. Variation in the factors associated with the prevalence of the 3 diseases examined in this study highlights the possibility that the spread of different diseases might require different management strategies. A greater understanding of the effects of fishing exclusion on the health of coral communities is also required before MPAs can be used as a management tool to influence the health of benthic communities in predictable and positive ways.

In conclusion, we did not find that MPAs in Palau consistently enhanced the health of acroporid and poritid assemblages by limiting the prevalence of diseases in these main disease hosts. A significant negative relationship between the prevalence of pooled diseases and the richness of a selection of reef fishes targeted by fishers, driven by a stronger association between the prevalence of SEB and fish species richness, is consistent with the hypothesis that increases in some kinds of fish play a role in minimising disease. Positive correlations between the prevalence of diseases pooled, the prevalence of SEB individually and the cover of the main disease host (acroporid and pocil- 
loporid corals) is a reminder that high densities of disease-susceptible coral taxa could facilitate the spread of disease, even within MPAs. Positive correlations between the prevalence of $\mathrm{BrB}$ and bleaching support the hypothesis that disease development is more likely in compromised coral hosts and suggests that BrB in particular is likely to increase concurrent with increases in the frequency and intensity of bleaching events with climate warming. Results of this study reveal the complexity of biotic and abiotic factors influencing disease prevalence in corals and highlight critical future priorities in understanding the interaction between fish community composition and health of corals.

Acknowledgements. This research was supported by funds provided by the World Bank/Global Environment Facility to the Targeted Coral Reef Research Coral Disease Working Group and the Palau International Coral Reef Centre (PICRC) and was also supported by James Cook University and the ARC Centre of Excellence for Coral Reef Studies. We thank staff at the PICRC and A. Ridep-Morris for assistance with field work, and C. Syms and M. McCormick for statistical advice. Comments by K. Kim, D. Williamson and 2 anonymous reviewers greatly improved this manuscript.

\section{LITERATURE CITED}

Aeby GS (1991) Behavioural and ecological relationship of a parasite and its hosts within a coral reef system. Pac Sci 45:263-269

Aeby GS, Santavy DL (2006) Factors affecting susceptibility of the coral Montastraea faveolata to black-band disease. Mar Ecol Prog Ser 318:103-110

Anderson RM, May RM (1979) Population biology of infectious diseases: Part I. Nature 280:361-367

Antonius A, Riegl B (1997) A possible link between coral disease and a corallivorous snail (Drupella cornus) outbreak in the Red Sea. Atoll Res Bull 47:1-9

Antonius A, Riegl B (1998) Coral diseases and Drupella cornus invasion in the Red Sea. Coral Reefs 17:48

Aronson RB, Precht WF (2001) White-band disease and the changing face of Caribbean reefs. Hydrobiologia 460: $25-38$

Ashworth JS, Ormond RFG, Sturrock HT (2004) Effects of reef-top gathering and fishing on invertebrate abundance across take and no-take zones. J Exp Mar Biol Ecol 303: 221-242

Bak RPM, Criens SR (1981) Survival after fragmentation of colonies of Madacis mirabilis, Acropora palmata and A. cervicornis (Scleractinia) and the subsequent impact of a coral disease. Proc 4th Int Coral Reef Symp Manila 2: 221-227

Banin E, Ben-Haim Y, Fine M, Israely T, Rosenberg E (2000) Virulence mechanisms of the coral bleaching pathogen Vibrio shiloi. Proc 9th Int Coral Reef Symp Bali 2: 1261-1266

Barber RT, Hilting AK, Hayes ML (2001) The changing health of coral reefs. Hum Ecol Risk Assess 7:1255-1270

Bellwood DR, Hoey AS, Choat JH (2003) Limited functional redundancy in high diversity systems: resilience and ecosystem function on coral reefs. Ecol Lett 6:281-285
Bellwood DR, Hughes TP, Hoey AS (2006) Sleeping functional group drives coral-reef recovery. Curr Biol 16:2434-2439

Ben-Haim Y, Zicherman-Keren M, Rosenberg E (2003) Temperature-regulated bleaching and lysis of the coral Pocillopora damicornis by the novel pathogen Vibrio coralliilyticus. Appl Environ Microbiol 69:4236-4242

Brown BE (1997) Coral bleaching: causes and consequences. Coral Reefs 16:S129-S138

Bruckner AW (2002) Priorities for effective management of coral diseases. NOAA Tech Memo NMFS-OPR-22. NOAA National Marine Fisheries Service, Silver Springs, MD

> Bruno JF, Petes LE, Harvell CD, Hettinger A (2003) Nutrient enrichment can increase the severity of coral disease. Ecol Lett 6:1056-1061

Bruno JF, Selig ER, Casey KS, Page CA and others (2007) Thermal stress as a driver of coral disease dynamics on the Great Barrier Reef. PLoS Biol 5:e124

> Coelho VR, Manfrino C (2007) Coral community decline at a remote Caribbean island: marine no-take reserves are not enough. Aquat Conserv Mar Freshw Ecosyst 17: 666-685

> Dalton S, Godwin S (2006) Progressive coral tissue mortality following predation by a corallivorous nudibranch Phestilla sp. Coral Reefs 25:529

Done T (2001) Scientific principles for establishing MPAs to alleviate coral bleaching and promote recovery. Proceedings of the workshop on mitigating coral bleaching impact through MPA design. Bishop Museum, Honolulu, HI, p 53-59

Dulvy NK, Sadovy Y, Reynolds JD (2003) Extinction vulnerability in marine populations. Fish Fish 4:25-64

> Dulvy MK, Freckelton RP, Polunin NVC (2004) Coral reef cascades and the indirect effects of predator removal by exploitation. Ecol Lett 7:410-416

Evans RD, Russ GR (2004) Larger biomass of targeted reef fish in no-take marine reserves on the Great Barrier Reef, Australia. Aquat Conserv Mar Freshw Ecosyst 14:505-519

Gardner TA, Cote IM, Gill JA, Grant A, Watkinson AR (2003) Long-term regions-wide declines in Caribbean corals. Science 301:958-960

> Graham NAJ, Wilson S, Jennings S, Polunin N, Bijoux J, Robinson J (2006) Dynamic fragility of oceanic coral reef ecosystems. Proc Natl Acad Sci USA 103:8425-8429

Halpern BS (2003) The impact of marine reserves: Do reserves work and does size matter? Ecol Appl 13 (Suppl): $117-137$

Harvell CD, Kim K, Burkholder J, Colwell RR and others (1999) Emerging marine diseases - climate links and anthropogenic factors. Science 285:1505-1510

Harvell CD, Mitchell CE, Ward JR, Altizer S, Dobson AP, Ostfeld RS, Samuel MD (2002) Climate warming and disease risk for terrestrial and marine biota. Science 296: $2158-2162$

Harvell C, Aronson R, Baron N, Connell J and others (2004) The rising tide of ocean diseases: unsolved problems and research priorities. Front Ecol Environ 2:375-382

> Hoegh-Guldberg O (1999) Climate change, coral bleaching and the future of the world's coral reefs. Mar Freshw Res 50:839-866

Hughes TP, Baird AH, Bellwood DR, Card M and others (2003) Climate change, human impacts and the resilience of coral reefs. Science 301:929-933

IPCC (2002) Climate change and biodiversity. Tech Pap V, Intergovernmental Panel on Climate Change, Geneva

Jackson JBC, Kirby MX, Berger WH, Bjorndal KA and others (2001) Historical overfishing and the recent collapse of coastal ecosystems. Science 293:629-637 
Jompa J, McCook LJ (2003) Contrasting effects of turf algae on corals: massive Porites spp. are unaffected by mixedspecies turfs, but killed by the red alga Anotrichium tenue. Mar Ecol Prog Ser 258:79-86

> Jones GP, McCormick MI, Srinivasan M, Eagle JV (2004a) Coral decline threatens fish biodiversity in marine reserves. Proc Natl Acad Sci USA 101:8251-8253

Kelly S, Scott D, MacDiarmid AB, Babcock RC (2000) Spiny lobster, Jasus edwardsii, recovery in New Zealand marine reserves. Biol Conserv 92:359-369

Kokita T, Nakazono A (2001) Rapid response of an obligately corallivorous filefish Oxymonacanthus longirostris (Monicanthidae) to a mass bleaching event. Coral Reefs 20: $155-158$

Kulbicki M (1998) How the acquired behaviour of commercial reef fishes may influence the results obtained from visual censuses. J Exp Mar Biol Ecol 222:11-30

Kushmaro A, Rosenberg E, Fine M, Ben Haim Y, Loya Y (1998) Effect of temperature on bleaching of the coral Oculina patagonica by Vibrio AK-1. Mar Ecol Prog Ser 171:131-137

Kuta KG, Richardson LL (2002) Ecological aspects of black band disease of corals: relationships between disease incidence and environmental factors. Coral Reefs 21: 393-398

Lafferty KD (2004) Fishing for lobsters indirectly increases epidemics in sea urchins. Ecol Appl 14:1566-1573

Marsh LM, Bradbury RH, Reichelt RE (1984) Determination of the physical parameters of coral distributions using line transect data. Coral Reefs 2:175-180

McCallum H, Harvell CD, Dobson AP (2003) Rates of spread of marine pathogens. Ecol Lett 6:1062-1067

McCallum H, Gerber K, Jani A (2005) Does infectious disease influence the efficacy of marine protected areas? A theoretical framework. J Appl Ecol 42:688-698

McClanahan TR (1997) Primary succession of coral-reef algae: differing patterns on fished versus unfished reefs. J Exp Mar Biol Ecol 218:77-102

> McClanahan TR, Mutere JC (1994) Coral and sea urchin assemblage structure and interrelationships in Kenyan reef lagoons. Hydrobiologia 286:109-124

McClanahan T, Muthiga N (1988) Changes in Kenyan coral reef community structure and function due to exploitation. Hydrobiologia 166:269-276

McClanahan T, McField M, Huitric M, Bergman K and others (2001) Responses of algae, corals and fish to the reductions of macroalgae in fished and unfished patch reefs of Glovers Reef Atoll, Belize. Coral Reefs 19:367-379

McClanahan T, Weil E, Maina J (2008) Strong relationship between coral bleaching and growth anomalies in massive Porites. Glob Change Biol 15:1804-1816

Miller J, Waara R, Muller E, Rogers C (2006) Coral bleaching and disease combine to cause extensive mortality on reefs in US Virgin Islands. Coral Reefs 25:418

Mitchell CE, Tilman D, Groth VJ (2002) Effects of grassland plant species diversity, abundance and composition on folicular fungal disease. Ecology 83:1713-1726

Muller EM, Rogers CS, Spitzack AS, van Woesik R (2008) Bleaching increases likelihood of disease on Acropora palmata (Lamarck) in Hawksnest Bay, St John, US Virgin Islands. Coral Reefs 27:191-195

> Mumby PJ, Dahlgren CP, Harbourne AR, Kappel CV and others (2006) Fishing, trophic cascades, and the process of grazing on coral reefs. Science 311:98-101

> Nugues MM, Smith GW, van Hooidonk RJ, Seabra MI, Bak RPM (2004) Algal contact as a trigger for coral disease. Ecol Lett 7:919-923
Page C, Willis B (2006) Distribution, host range and largescale spatial variability in black band disease prevalence on the Great Barrier Reef, Australia. Dis Aquat Org 69:41-51

> Page CA, Willis BL (2008) Epidemiology of skeletal eroding band on the Great Barrier Reef and the role of injury in the initiation of this widespread coral disease. Coral Reefs $27: 257-272$

Patterson KL, Porter JW, Ritchie KB, Polson SW and others (2002) The etiology of white pox, a lethal disease of the Caribbean elkhorn coral, Acropora palmata. Proc Natl Acad Sci USA 99:8725-8730

> Polunin NVC, Roberts CM (1993) Greater biomass and value of target coral-reef fishes in two small Caribbean marine reserves. Mar Ecol Prog Ser 100:167-176

> Porter J, Dustan P, Jaap W, Patterson KL and others (2001) Patterns of spread of coral disease in the Florida Keys. Hydrobiologia 460:1-24

Raymundo LJ, Rosell KB, Reboton CT, Kaczmarsky L (2005) Coral disease on Philippine reefs: genus Porites is a dominant host. Dis Aquat Org 64:181-191

Russ GR (2002) Yet another review of marine reserves as reef fisheries management tools. In: Sale P (ed) Coral reef fishes: dynamics and diversity in a complex ecosystem. Academic Press, San Diego, CA, p 421-443

Sasal P, Desdevises Y, Durieux E, Lenfants P, Romans P (2004) Parasites in marine protected areas: success and specificity of monogeneans. J Fish Biol 64:370-379

Selig ER, Harvell CD, Bruno JF, Willis BL, Page CA, Casey KS, Sweatman H (2006) Analyzing the relationship between ocean temperature anomalies and coral disease outbreaks at broad spatial scales. In: Phinney J, HoeghGuldberg O, Kleypas J, Skirving W, Strong A (eds) Coral reefs and climate change. Coastal and Estuarine Series Vol 61. American Geological Union, p 111-128

Shibuno T, Hashimoto K, Abe O, Takada Y (1999) Shortterm changes in the structure of a fish community following coral bleaching at Ishigaki Island, Japan. Galaxia 1: $51-58$

Smith JE, Shaw M, Edwards RA, Obura D and others (2006) Indirect effects of algae on coral: algae-mediated, microbe-induced coral mortality. Ecol Lett 9:835-845

Sokolow S (2009) Effects of a changing climate on the dynamics of coral infectious disease: a review of the evidence. Dis Aquat Org 87:5-18

Sussman M, Loya Y, Fine M, Rosenberg E (2003) The marine fireworm Hermodice carunculata is a winter reservoir and spring-summer vector for the coral bleaching pathogen Vibrio shiloi. Environ Microbiol 5:250-255

Uthicke S, Welch D, Benzie J (2004) Slow growth and lack of recovery of holothurians on the Great Barrier Reef from DNA fingerprints and repeated large-scale surveys. Conserv Biol 18:1395-1404

> Voss JD, Richardson LJ (2006) Nutrient enrichment enhances black band disease progression in corals. Coral Reefs 25:569-576

> Ward JR, Lafferty KD (2004) The elusive baseline of marine disease: Are diseases in ocean ecosystems increasing? PLoS Biol 2:e120

Ward JR, Rypien KL, Bruno JF, Harvell CD and others (2006) Coral diversity and disease in Mexico. Dis Aquat Org 69:23-31

Ward J, Kim K, Harvell CD (2007) Temperature affects coral disease resistance and pathogen growth. Mar Ecol Prog Ser 329:115-121

Weil E, Urreiztieta I, Garzon-Ferreira J (2002) Geographic variability in the incidence of coral and octocoral disease 
in the wider Caribbean. Proc 9th Int Coral Reef Symp Bali 2:1231-1237

White AT (1986) Marine reserves: how effective as management strategies for Phillippine, Indonesian and Malaysian coral reef environments? Ocean Manag 10: 137-159

- Williams DM (1986) Temporal variation in the structure of reef slope fish communities (central Great Barrier Reef): short term effects of Acanthaster planci infestations. Mar Ecol Prog Ser 28:157-164

Editorial responsibility: Kiho Kim, Washington, DC, USA
Williams DE, Miller MW (2005) Coral disease outbreak: patterns, prevalence and transmission in Acropora cervicornis. Mar Ecol Prog Ser 301:119-128

Williamson DH, Russ GR, Ayling AM (2004) No-take marine reserves increase abundance and biomass of reef fish on inshore fringing reefs of the Great Barrier Reef. Environ Conserv 31:149-159

Willis BL, Page CA, Dinsdale EA (2004) Coral disease on the Great Barrier Reef. In: Rosenberg E, Loya Y (eds) Coral disease and health. Springer-Verlag, Berlin, p 69-104

Submitted: December 19, 2008; Accepted: July 1, 2009 Proofs received from author(s): September 16, 2009 